\title{
Jolanta Wiśniewska
}

\section{Korzyści świadczenia usług finansowo-księgowych w MSP województwa kujawsko-pomorskiego}

Kody JEL: M40, M41

Słowa kluczowe: usługi finansowo-księgowe, outsourcing, małe i średnie przedsiębiorstwa

Streszczenie. Coraz więcej firm zleca na zewnątrz zadania $\mathrm{z}$ zakresu finansów i rachunkowości z uwagi na uzyskiwane korzyści, wynikające z większej wydajności i skuteczności prowadzonych działań. Zlecanie funkcji finansowo-księgowych specjalistycznym firmom przynosi nie tylko oszczędności, ale daje możliwość dostępu do wiedzy i umiejętności wysoko wykwalifikowanych kadr. Obecnie obserwuje się coraz większy rozwój outsourcingu funkcji finansowo-księgowych. Przedsiębiorstwa całkowicie wyprowadzają je na zewnątrz lub korzystają z części ich obszarów. Celem artykułu jest przedstawienie efektów uzyskiwanych przez przedsiębiorstwa sektora MSP województwa kujawsko-pomorskiego z korzystania z profesjonalnych usług finansowo-księgowych. Przeprowadzone badania ujawniły, że najczęściej obszar, w którym stosowany jest outsourcing funkcji finansowo-księgowych, dotyczy prowadzenia ksiąg rachunkowych, a w następnej kolejności, na równi opracowywania i przygotowywania dokumentacji księgowej i sprawozdawczości finansowej. W wyniku powierzenia specjalistycznym firmom zadań z zakresu finansów i rachunkowości przedsiębiorstwa uzyskują wiele korzyści w każdym obszarze swojej działalności. 


\section{Wprowadzenie}

Mikro, małe i średnie przedsiębiorstwa odgrywają bardzo ważną rolę w gospodarce każdego kraju i jest wiele argumentów, zarówno jakościowych, jak i ilościowych, potwierdzających tę opinię (Ignatiuk, 2011). Przedsiębiorstwa te uważane są za stymulatora rozwoju gospodarki, a ich funkcjonowanie stanowi przejaw zdrowej konkurencji oraz odzwierciedla przedsiębiorczość społeczeństwa (Ignatiuk, 2011; Nieć, 2015). Rola odgrywana przez te podmioty w gospodarce oraz na rynku pracy sprawia, że tworzenie warunków sprzyjających ich powstawaniu i rozwojowi leży w interesie społecznym (Chrościcka, Płachecki, Stasiowski, 2010). Znaczenie przedsiębiorstw sektora MSP jest również istotne $\mathrm{z}$ uwagi na możliwość szybkiego reagowania na zmieniające się otoczenie (Ignatiuk, 2013). Zarówno o rozwoju gospodarki całego kraju, jak i danego regionu w znacznym stopniu decyduje ilość i jakość podmiotów sektora MSP (Nieć, 2015).

W Polsce większość firm działających na rynku stanowią mikro, małe i średnie przedsiębiorstwa, które generowały w 2012 roku 48,5\% PKB (Łapiński, Nieć, Rzeźnik, Węcławska, 2015). Województwo kujawskopomorskie nie wyróżnia się pod tym względem z reszty kraju. Większość firm działających na tym terenie to przedsiębiorstwa sektora MSP, które coraz częściej korzystają z usług wyspecjalizowanych firm w zakresie finansów i rachunkowości. Do udzielania przedsiębiorstwom skutecznego wsparcia potrzebna jest odpowiednia wiedza o ich kondycji i potrzebach, uwarunkowaniach w jakich funkcjonują, a także o instytucjach należących do ich otoczenia, które skutecznie będą wspierać ich działalność i przyczyniać się do ich rozwoju.

Outsourcing funkcji finansowo-księgowych jest coraz częściej stosowany przez przedsiębiorstwa różnej wielkości (Michael, 2015). Pozwala wykonywać pracę nie tylko wydajniej, ale też skuteczniej. Jedną z rozwojowych tendencji $\mathrm{w}$ gospodarce światowej jest delegowanie funkcji, które nie są związane z podstawową działalnością firmy do dostawców usług outsourcingowych (Power, Desouza, Bonifazi, 2010; Raluca, 2015). Zlecając pracę wyspecjalizowanym firmom, przedsiębiorstwa korzystają $\mathrm{z}$ ich wiedzy i doświadczenia (Power i inni, 2010).

Celem artykułu jest przedstawienie korzyści uzyskanych przez przedsiębiorstwa sektora MSP ze zlecania funkcji finansowo-księgowych zewnętrznym wyspecjalizowanym firmom. 


\section{Metodyka i przebieg procesu badawczego}

Cel opracowania został zrealizowany za pomocą następujących metod badawczych: studiów literaturowych, analizy aktów prawnych, badania ankietowego i wnioskowania.

Badanie empiryczne, którego wyniki przedstawiono w artykule, było częścią szerszego badania ankietowego, przeprowadzonego przez autorkę. Przedstawione wyniki dotyczą części badania, w którym wzięli udział pracownicy przedsiębiorstw, uczestniczący w szkoleniach i kursach specjalistycznych z finansów i rachunkowości organizowanych przez Oddział Okręgowy Stowarzyszenia Księgowych w Polsce w Toruniu (od kwietnia do maja 2014 r.) - 153 osoby. Badanie realizowano metodą ankiety audytoryjnej. Kwestionariusz ankiety składał się z dwóch części - pierwsza zawierała 9 pytań dotyczących podstawowych danych o firmach, w których pracowali respondenci biorący udział w badaniu, druga część zawierała zaś 10 pytań dotyczących zapotrzebowania tych przedsiębiorstw na usługi doradcze z zakresu finansów i rachunkowości. Kwestionariusz ankiety rozdano wszystkim uczestnikom szkoleń i kursów. Otrzymano 115 kwestionariuszy poprawnie wypełnionych, co daje zwrotność łączną na poziomie $75,8 \%$.

Strukturę respondentów z uwzględnieniem rodzaju reprezentowanego przez nich przedsiębiorstwa przedstawiono w tabeli 1.

Tabela 1

Struktura respondentów reprezentujących poszczególne rodzaje przedsiębiorstw

\begin{tabular}{|l|c|c|}
\hline \multicolumn{1}{|c|}{ Wyszczególnienie } & Liczba & $\%$ \\
\hline Mikroprzedsiębiorstwa & 40 & 34,5 \\
\hline Małe przedsiębiorstwa & 29 & 25,0 \\
\hline Średnie przedsiębiorstwa & 38 & 32,8 \\
\hline Duże przedsiębiorstwa & 9 & 7,7 \\
\hline Razem & 116 & 100,0 \\
\hline
\end{tabular}

Źródło: opracowanie własne na podstawie przeprowadzonego badania ankietowego.

$\mathrm{Z}$ analizy przedstawionej w tabeli 1 wynika, że 92,3\% respondentów biorących udział w badaniu reprezentowało sektor MSP.

\section{Outsourcing usług finansowo-księgowych}

Pojęcie „outsourcing” oznacza zlecanie pracy, odpowiedzialności i uprawnień decyzyjnych zewnętrznej firmie (Power i in., 2010). Jest skrótem od angielskiego terminu ,outside resource using”, czyli wykorzystywania zasobów zewnętrznych do realizacji własnych celów organizacji (Trocki, 
2001; Zieliński, 2015). W Słowniku języka polskiego (2015) można znaleźć definicję outsourcing jako strategię zarządzania, która polega na zlecaniu wyspecjalizowanej zewnętrznej firmie wykonanie zadań, które nie są bezpośrednio związane z podstawowym profilem działalności firmy zlecającej.

Do najbardziej popularnych zadań oddawanych w outsourcing zalicza się, m.in. (KPMG, 2015; Kuźma, 2015; Wojciechowski, 2015):

- finanse i rachunkowość,

- obsługę klienta,

- administrację funkcji kadrowych,

- obsługę płac,

- zarządzanie danymi,

- szkolenia,

- wsparcie IT,

- podatki,

- zaopatrzenie.

Z przedstawionych zadań oddawanych przez przedsiębiorstwa $\mathrm{w}$ outsourcing wynika, że większość $\mathrm{z}$ nich wchodzi w zakres usług finansowoksięgowych.

Wszystkie rodzaje przedsiębiorstw mogą korzystać z outsourcingu usług finansowo-księgowych. Wielkość firmy determinuje zaś zakres i ilość pracy, która ma być wykonana przez zewnętrzną firmę (Raluca, 2015). Przedsiębiorstwa należące do sektora MSP, ze względu na swoją wielkość, jak również konieczność pracy na rynku bardzo konkurencyjnym, są coraz bardziej zainteresowane przekazywaniem funkcji pobocznych wyspecjalizowanym firmom i koncentrowanie się na kluczowych kompetencjach (Power i in., 2010). W zależności od wielkości firmy mogą zdecydować się na jeden $\mathrm{z}$ trzech rodzajów outsourcingu funkcji finansowo-księgowych (Trocki, 2001; Raluca, 2015):

- outsourcing pojedynczych funkcji,

- outsourcing funkcji powiązanych w formie procesów,

- outsourcing obszarów funkcjonalnych.

Do podstawowych korzyści uzyskiwanych z tego tytułu należą (Zieliński, 2015):

- redukcja kosztów,

- dążenie do realizacji usług na najwyższym poziomie,

- specjalizacja pracy,

- koncentracja na funkcjach biznesowych,

- dostęp do specjalistycznej wiedzy.

Oprócz korzyści wiążących się z przekazywaniem funkcji finansowoksięgowym wyspecjalizowanym firmom również mogą wystąpić zagrożenia, do których można zaliczyć m.in. (Trocki, 2001): 
- brak precyzyjnej i pełnej informacji o kosztach outsourcingu,

- brak strategii i planów leżących u podstaw decyzji outsourcingowych,

- brak prawidłowej i efektywnej komunikacji,

- brak akceptacji i wsparcia części kierownictwa i pracowników,

- niewłaściwy wybór firmy outsourcingowej,

- nieprawidłowo prowadzone negocjacje,

- źle sformułowana umowa,

- brak restrukturyzacji towarzyszącej wydzieleniu funkcji.

Funkcje dotyczące finansów i rachunkowości wchodzą w skład funkcji kierowniczych przedsiębiorstwa (Trocki, 2001), dlatego decyzja o ich przekazaniu firmom zewnętrznym musi być dobrze przemyślana i przygotowana przez przedsiębiorstwo w celu maksymalizacji korzyści i zminimalizowaniu zagrożeń z tym związanych.

\section{Obszary usług finansowo-księgowych}

Zakres usług finansowo-księgowych wykonywanych przez wyspecjalizowane firmy może dotyczyć różnych obszarów organizacji rachunkowości w firmie. Organizacja rachunkowości w firmie dzieli się na dwie grupy: organizacja działu rachunkowości i organizacja procesu informacyjnego w przedsiębiorstwie (Kiziukiewicz, 2002; Judkowiak, 2011), natomiast te z kolei mogą wpływać w sposób bezpośredni lub pośredni na inne obszary działalności organizacji. Zakres usług finansowo-księgowych według obszarów korzyści wskazanych przez respondentów przedstawiono w tabeli 2.

Respondenci wskazali, że najwięcej korzyści ze zlecania wyspecjalizowanym firmom funkcji finansowo-księgowych dotyczyło organizacji procesu informacyjnego w przedsiębiorstwie $(59,5 \%)$, w tym w szczególności ewidencji księgowej i sprawozdawczości (po 19,1\%), w następnej kolejności - dokumentacji księgowej $(13,7 \%)$. Na drugim miejscu respondenci wskazali usługi dotyczące organizacji działu rachunkowości (26,8\%), w tym zagadnień organizacyjnych związanych z działem księgowości (12,2\%), a następnie doboru i przygotowania personelu (7,6\%). Respondenci również wskazali na związek tych usług z innymi zagadnieniami, wpływającymi na działalność jednostki (13,7\%). 
Tabela 2

Obszary korzyści usług finansowo-księgowych

\begin{tabular}{|c|c|c|c|c|c|c|c|c|c|}
\hline \multirow[t]{2}{*}{ Obszary korzyści } & \multicolumn{2}{|c|}{$\begin{array}{l}\text { Mikro } \\
\text { przedsię- } \\
\text { biorstwa }\end{array}$} & \multicolumn{2}{|c|}{$\begin{array}{l}\text { Małe przed- } \\
\text { siębiorstwa }\end{array}$} & \multicolumn{2}{|c|}{$\begin{array}{l}\text { Średnie } \\
\text { przedsię- } \\
\text { biorstwa }\end{array}$} & \multicolumn{3}{|c|}{ Razem } \\
\hline & liczba & $\%$ & liczba & $\%$ & liczba & $\%$ & liczba & $\%$ & $\%$ \\
\hline \multicolumn{10}{|c|}{ Organizacja działu rachunkowości } \\
\hline $\begin{array}{l}\text { Organizacja działu } \\
\text { księgowości w jedno- } \\
\text { stce }\end{array}$ & 4 & 10,8 & 3 & 13,6 & 9 & 12,5 & 16 & 12,2 & \multirow{3}{*}{26,8} \\
\hline $\begin{array}{l}\text { Wyposażenie tech- } \\
\text { niczne działu księ- } \\
\text { gowości }\end{array}$ & 3 & 8,1 & 1 & 4,5 & 5 & 6,9 & 9 & 7,0 & \\
\hline $\begin{array}{l}\text { Dobór i przygotowa- } \\
\text { nie personelu }\end{array}$ & 4 & 10,8 & 1 & 4,5 & 5 & 6,9 & 10 & 7,6 & \\
\hline \multicolumn{10}{|c|}{ Organizacja procesu informacyjnego } \\
\hline $\begin{array}{l}\text { Dokumentacja księ- } \\
\text { gowa (rodzaje, wy- } \\
\text { stawianie, kontrola, } \\
\text { obieg i przechowy- } \\
\text { wanie dokumentów) }\end{array}$ & 6 & 16,2 & 4 & 18,2 & 8 & 11,1 & 18 & 13,7 & \multirow{4}{*}{59,5} \\
\hline Ewidencja księgowa & 8 & 21,6 & 6 & 27,5 & 11 & 15,3 & 25 & 19,1 & \\
\hline $\begin{array}{l}\text { Inwentaryzacja } \\
\text { i kontrola wewnętrzna }\end{array}$ & 3 & 8,1 & 1 & 4,5 & 6 & 8,3 & 10 & 7,6 & \\
\hline $\begin{array}{l}\text { Sprawozdawczość } \\
\text { (rodzaje, zasady } \\
\text { sporządzania, bada- } \\
\text { nia, zatwierdzania) }\end{array}$ & 5 & 13,6 & 3 & 13,6 & 17 & 23,7 & 25 & 19,1 & \\
\hline \multicolumn{10}{|c|}{ Pozostałe zagadnienia } \\
\hline $\begin{array}{l}\text { Pozostałe zagadnie- } \\
\text { nia }\end{array}$ & 4 & 10,8 & 3 & 13,6 & 11 & 15,3 & 18 & 13,7 & 13,7 \\
\hline Razem & 37 & 100,0 & 22 & 100,0 & 72 & 100,0 & 131 & 100,0 & 100,0 \\
\hline
\end{tabular}

Źródło: opracowanie własne na podstawie przeprowadzonego badania.

\section{Korzyści z outsourcingu usług finansowo-księgowych}

Przy prowadzeniu działalności gospodarczej zarządzający małymi przedsiębiorstwami korzystają z różnego rodzaju informacji. W celu sprawnego zarządzania powinni otrzymywać dobre jakościowo informacje w odpowiednim czasie (Martyniuk-Kwiatkowska, 2009). Podstawowym źródłem informacji o sytuacji finansowej i majątkowej każdego przedsiębiorstwa jest system rachunkowości. Organizacja tego systemu ma wpływ na liczbę i jakość informacji finansowych uzyskiwanych przez właścicieli i zarządzających przedsiębiorstwem (Martyniuk-Kwiatkowska, 2009). 
Tabela 3

Korzyści z outsourcingu funkcji finansowo-księgowych dotyczące procesu informacyjnego rachunkowości

\begin{tabular}{|c|c|c|c|c|c|c|c|c|}
\hline \multirow[t]{2}{*}{ Rodzaje korzyści } & \multicolumn{2}{|c|}{$\begin{array}{l}\text { Mikro } \\
\text { przedsię- } \\
\text { biorstwa }\end{array}$} & \multicolumn{2}{|c|}{$\begin{array}{l}\text { Małe przed- } \\
\text { siębiorstwa }\end{array}$} & \multicolumn{2}{|c|}{$\begin{array}{l}\text { Średnie } \\
\text { przedsię- } \\
\text { biorstwa }\end{array}$} & \multicolumn{2}{|c|}{ Razem } \\
\hline & liczba & $\%$ & liczba & $\%$ & liczba & $\%$ & liczba & $\%$ \\
\hline \multicolumn{9}{|c|}{ Ewidencja księgowa } \\
\hline $\begin{array}{l}\text { Plan kont dostosowany do } \\
\text { potrzeb jednostki }\end{array}$ & 1 & 7,6 & 2 & 18,1 & 3 & 21,4 & 6 & 15,8 \\
\hline $\begin{array}{l}\text { Profesjonalne prowadzenie } \\
\text { ksiąg rachunkowych przez } \\
\text { wysoko wykwalifikowanych } \\
\text { pracowników }\end{array}$ & 6 & 46,2 & 4 & 36,4 & 1 & 7,2 & 11 & 28,9 \\
\hline $\begin{array}{l}\text { Doradztwo i śledzenie przepi- } \\
\text { sów prawnych przez fachow- } \\
\text { ców z dziedziny rachunkowo- } \\
\text { ści i podatków }\end{array}$ & 6 & 46,2 & 5 & 45,5 & 7 & 50,0 & 18 & 47,4 \\
\hline Żadne & 0 & 0,0 & 0 & 0,0 & 3 & 21,4 & 3 & 7,9 \\
\hline $\begin{array}{l}\text { Spowodowały negatywne } \\
\text { skutki }\end{array}$ & 0 & 0,0 & 0 & 0,0 & 0 & 0,0 & 0 & 0,0 \\
\hline Razem & 13 & 100,0 & 11 & 100,0 & 14 & 100,0 & 38 & 100,0 \\
\hline \multicolumn{9}{|c|}{ Sprawozdawczość (rodzaje, zasady sporządzania, badanie, zatwierdzanie) } \\
\hline $\begin{array}{l}\text { Szybkie uzyskiwanie informa- } \\
\text { cji }\end{array}$ & 1 & 9,1 & 1 & 16,7 & 4 & 13,8 & 6 & 13,0 \\
\hline $\begin{array}{l}\text { Uzyskiwanie informacji w róż- } \\
\text { nych przekrojach informacyj- } \\
\text { nych }\end{array}$ & 2 & 18,2 & 1 & 16,7 & 3 & 10,3 & 6 & 13,0 \\
\hline $\begin{array}{l}\text { Przygotowywanie niezbędnej } \\
\text { sprawozdawczości na potrzeby } \\
\text { wewnętrzne jednostki }\end{array}$ & 1 & 9,1 & 1 & 16,7 & 3 & 10,3 & 5 & 10,9 \\
\hline $\begin{array}{l}\text { Elastyczność tworzenia spra- } \\
\text { wozdawczości wewnętrznej }\end{array}$ & 0 & 0,0 & 0 & 0,0 & 2 & 7,0 & 2 & 4,4 \\
\hline $\begin{array}{l}\text { Potwierdzenie prawidłowości } \\
\text { sporządzania i informacji za- } \\
\text { wartych w sprawozdaniu finan- } \\
\text { sowym }\end{array}$ & 6 & 54,5 & 2 & 33,2 & 11 & 38,0 & 19 & 41,3 \\
\hline $\begin{array}{l}\text { Uniknięcie błędów, kar i zwro- } \\
\text { tów otrzymanych dotacji }\end{array}$ & 1 & 9,1 & 1 & 16,7 & 3 & 10,3 & 5 & 10,9 \\
\hline Żadne & 0 & 0,0 & 0 & 0,0 & 3 & 10,3 & 3 & 6,5 \\
\hline $\begin{array}{l}\text { Spowodowały negatywne } \\
\text { skutki }\end{array}$ & 0 & 0,0 & 0 & 0,0 & 0 & 0,0 & 0 & 0,0 \\
\hline Razem & 11 & 100,0 & 6 & 100,0 & 29 & 100,0 & 46 & 100,0 \\
\hline
\end{tabular}

Źródło: opracowanie własne na podstawie przeprowadzonego badania. 
Tabela 4

Korzyści z outsourcingu funkcji finansowo-księgowych dotyczące organizacji działu księgowości

\begin{tabular}{|c|c|c|c|c|c|c|c|c|}
\hline \multirow{2}{*}{ Rodzaje korzyści } & \multicolumn{2}{|c|}{$\begin{array}{l}\text { Mikro przedsię- } \\
\text { biorstwa }\end{array}$} & \multicolumn{2}{|c|}{$\begin{array}{l}\text { Małe przedsię- } \\
\text { biorstwa }\end{array}$} & \multicolumn{2}{|c|}{$\begin{array}{l}\text { Srednie przed- } \\
\text { siębiorstwa }\end{array}$} & \multicolumn{2}{|c|}{ Razem } \\
\hline & liczba & $\%$ & liczba & $\%$ & liczba & $\%$ & liczba & $\%$ \\
\hline \multicolumn{9}{|c|}{ Organizacja działu księgowości w jednostce } \\
\hline $\begin{array}{l}\text { Prawidłowa lokaliza- } \\
\text { cja działu rachunko- } \\
\text { wości w jednostce }\end{array}$ & 0 & 0,0 & 0 & 0,0 & 2 & 11,8 & 2 & 6,9 \\
\hline $\begin{array}{l}\text { Informacje dla celów } \\
\text { zarządczych uzyski- } \\
\text { wane są w odpo- } \\
\text { wiednim czasie } \\
\end{array}$ & 1 & 16,7 & 1 & 16,7 & 2 & 11,8 & 4 & 13,8 \\
\hline $\begin{array}{l}\text { Zmniejszenie liczby } \\
\text { błędów związanych } \\
\text { ze sporządzaniem } \\
\text { dokumentów księ- } \\
\text { gowych }\end{array}$ & 1 & 16,7 & 1 & 16,7 & 4 & 23,4 & 6 & 20,7 \\
\hline $\begin{array}{l}\text { Efektywniejsze } \\
\text { wykorzystanie pracy } \\
\text { poszczególnych } \\
\text { pracowników }\end{array}$ & 0 & 0,0 & 1 & 16,7 & 2 & 11,8 & 3 & 10,3 \\
\hline $\begin{array}{l}\text { Lepsza organizacji } \\
\text { pracy }\end{array}$ & 1 & 16,7 & 1 & 16,7 & 3 & 17,6 & 5 & 17,2 \\
\hline $\begin{array}{l}\text { Zmniejszenie kosz- } \\
\text { tów działu rachun- } \\
\text { kowości }\end{array}$ & 1 & 16,7 & 1 & 16,6 & 1 & 5,9 & 3 & 10,3 \\
\hline $\begin{array}{l}\text { Zoptymalizowanie } \\
\text { obiegu dokumentów } \\
\text { księgowych }\end{array}$ & 1 & 16,6 & 1 & 16,6 & 2 & 11,8 & 4 & 13,8 \\
\hline Żadne & 1 & 16,6 & 0 & 0,0 & 1 & 5,9 & 2 & 7,0 \\
\hline $\begin{array}{l}\text { Spowodowały nega- } \\
\text { tywne skutki }\end{array}$ & 0 & 0,0 & 0 & 0,0 & 0 & 0,0 & 0 & 0,0 \\
\hline Razem & 6 & 100,0 & 6 & 100,0 & 17 & 100,0 & 29 & 100,0 \\
\hline \multicolumn{9}{|c|}{ Dobór i przygotowania personelu } \\
\hline $\begin{array}{l}\text { Zatrudnienie pra- } \\
\text { cowników o odpo- } \\
\text { wiednich kwalifika- } \\
\text { cjach zawodowych }\end{array}$ & 2 & 28,6 & 0 & 0,0 & 3 & 42,8 & 5 & 33,3 \\
\hline $\begin{array}{l}\text { Zbudowanie stałego } \\
\text { zespołu pracowników }\end{array}$ & 2 & 28,6 & 1 & 100,0 & 2 & 28,6 & 5 & 33,3 \\
\hline $\begin{array}{l}\text { Odpowiedni zakres } \\
\text { czynności dla pra- } \\
\text { cowników }\end{array}$ & 3 & 42,8 & 0 & 0,0 & 2 & 28,6 & 5 & 33,4 \\
\hline Żadne & 0 & 0,0 & 0 & 0,0 & 0 & 0,0 & 0 & 0,0 \\
\hline $\begin{array}{l}\text { Spowodowały nega- } \\
\text { tywne skutki }\end{array}$ & 0 & 0,0 & 0 & 0,0 & 0 & 0,0 & 0 & 0,0 \\
\hline Razem & 7 & 100,0 & 1 & 100,0 & 7 & 100,0 & 15 & 100,0 \\
\hline
\end{tabular}

Źródło: opracowanie własne na podstawie przeprowadzonego badania. 
Korzyści uzyskiwane $\mathrm{z}$ outsourcingu funkcji finansowo-księgowych w przedsiębiorstwach województwa kujawsko-pomorskiego dotyczące procesu informacyjnego organizacji przedstawiono w tabeli $3^{1}$.

W obszarze dotyczącym ewidencji księgowej respondenci najczęściej wskazują na występowanie korzyści dotyczących doradztwa oraz śledzenia przepisów podatkowych i rachunkowych przez fachowców $(47,4)$, w drugiej kolejności z tytułu profesjonalnego prowadzenie ksiąg rachunkowych przez wysoko wykwalifikowanych specjalistów (28,9\%), a następnie korzyści dotyczące profesjonalnego, opracowania dostosowanego do potrzeb informacyjnych jednostki zakładowego planu kont $(15,8 \%)$. W obszarze organizacji procesu informacyjnego dotyczącego sprawozdawczości, respondenci najczęściej wskazywali na korzyści dotyczące potwierdzania prawidłowości sporządzania i informacji zawartych w sprawozdaniu finansowym $(41,31 \%)$, w następnej kolejności na równi - na korzyści dotyczące szybkości uzyskiwania informacji oraz uzyskiwanie informacji $\mathrm{w}$ różnych przekrojach informacyjnych (po 13\%).

Pomiędzy organizacją procesu informacyjnego i organizacją działu rachunkowości zachodzą różne powiązania i uwarunkowania. Dział rachunkowości powinien być tak zorganizowany, żeby wykonywane w nim zadania były wykonywane rzetelnie, bezbłędnie, sprawdzalnie i bieżąco (Ustawa o rachunkowości, 1994). Organizacja działu rachunkowości jest uzależniona przede wszystkim od wielkości przedsiębiorstwa. Prowadzenie rachunkowości niezależnie od wielkości przedsiębiorstwa może być zlecane podmiotom zewnętrznym, przy czym zakres prac w przedsiębiorstwach sektora MSP będzie inny niż w przedsiębiorstwach dużych.

Korzyści uzyskiwane przez przedsiębiorstwa sektora MSP dotyczące organizacji działu księgowości przedstawiono w tabeli $4^{2}$.

Korzyści uzyskiwane przez podmioty dotyczyły najczęściej dwóch obszarów - organizacji pracy w dziale/komórce księgowości oraz doboru i przygotowania personelu. W pierwszym $\mathrm{z}$ tych obszarów respondenci wskazywali najczęściej na korzyść polegającą na zmniejszeniu liczby błędów związanych ze sporządzaniem dokumentów księgowych w firmie $(20,7 \%)$, w następnej kolejności lepszą organizację pracy działu księgowości $(17,2 \%)$ i na równi uzyskiwaniu w odpowiednim czasie informacji dla celów zarządczych oraz zoptymalizowanie obiegu dokumentów (po 13,8\%). W drugim obszarze wskazano na równi na trzy korzyści: zatrudnianie pra-

\footnotetext{
${ }^{1}$ Ze względu na ograniczoną objętość tego opracowania, ograniczono się jedynie do dwóch obszarów korzyści procesu informacyjnego rachunkowości.

${ }^{2}$ Ze względu na ograniczoną objętość tego opracowania, ograniczono się jedynie do dwóch obszarów korzyści organizacji działu rachunkowości.
} 
cowników z odpowiednimi kwalifikacjami zawodowych, zbudowanie stałego zespołu i odpowiedni zakres czynności dla pracowników (po 33,3\%).

Efekty powierzenia specjalistycznym firmom usług finansowoksięgowych kojarzone są przede wszystkim z organizacją działu i procesu informacyjnego $\mathrm{w}$ jednostce, co wpływa bezpośrednio lub pośrednio na wszystkie działania przedsiębiorstwa i na funkcjonowanie, rozwój i ograniczenie ryzyka jego działalności. Korzyści uzyskiwane z outsourcingu funkcji finansowo-księgowych dla pozostałych zagadnień związanych z działalnością jednostki wskazane przez respondentów przedstawiono w tabeli 5 .

Tabela 5

Pozostałe korzyści z outsourcingu funkcji finansowo-księgowych

\begin{tabular}{|l|c|c|c|c|c|c|c|c|}
\hline \multirow{2}{*}{ Rodzaje korzyści } & \multicolumn{2}{|c|}{$\begin{array}{c}\text { Mikro przed- } \\
\text { siębiorstwa }\end{array}$} & \multicolumn{2}{c|}{$\begin{array}{c}\text { Małe przedsię- } \\
\text { biorstwa }\end{array}$} & \multicolumn{2}{c|}{$\begin{array}{c}\text { Średnie przed- } \\
\text { siębiorstwa }\end{array}$} & \multicolumn{2}{c|}{ Razem } \\
\cline { 2 - 10 } & liczba & $\%$ & liczba & $\%$ & liczba & $\%$ & liczba & $\%$ \\
\hline $\begin{array}{l}\text { Uniknięcie błędów w } \\
\text { tworzeniu, przekształ- } \\
\text { ceniu, likwidacji } \\
\text { jednostki }\end{array}$ & 1 & 16,7 & 0 & 0,0 & 3 & 27,3 & 4 & 19,0 \\
\hline $\begin{array}{l}\text { Pozyskanie nowych } \\
\text { źródeł finansowania }\end{array}$ & 2 & 33,3 & 1 & 25,0 & 6 & 54,5 & 9 & 42,9 \\
\hline $\begin{array}{l}\text { Pozyskanie nowych } \\
\text { inwestorów }\end{array}$ & 0 & 0,0 & 0 & 0,0 & 0 & 0,0 & 0 & 0,0 \\
\hline $\begin{array}{l}\text { Pozyskanie nowych } \\
\text { klientów }\end{array}$ & 2 & 33,3 & 3 & 75,0 & 1 & 9,1 & 6 & 28,6 \\
\hline Żadne & 1 & 16,7 & 0 & 0,0 & 1 & 9,1 & 2 & 9,5 \\
\hline $\begin{array}{l}\text { Spowodowały nega- } \\
\text { tywne skutki }\end{array}$ & 0 & 0,0 & 0 & 0,0 & 0 & 0,0 & 0 & 0,0 \\
\hline Razem & 6 & 100,0 & 4 & 100,0 & 11 & 100,0 & 21 & 100,0 \\
\hline
\end{tabular}

Źródło: opracowanie własne na podstawie przeprowadzonego badania.

Na podstawie danych $w$ tabeli 5 można zaobserwować, że najczęściej wskazywana przez respondentów korzyść dotyczy pozyskiwania nowych źródeł finansowania (42,9\%), w następnej kolejności - pozyskiwania nowych klientów $(28,6 \%)$ oraz unikania błędów w tworzeniu, przekształcaniu i likwidacji przedsiębiorstw (19,0\%).

\section{Podsumowanie}

Usługi finansowo-księgowe zapewniają małym przedsiębiorstwom właściwe doradztwo oraz profesjonalne wsparcie. Właściciele firm potrzebują specjalistów, którzy im doradzą i wspomogą w prowadzeniu działalności gospodarczej. Wyniki badania przeprowadzone w województwie kujawskopomorskim wykazały, że korzystanie $\mathrm{z}$ outsourcingu funkcji finansowo- 
księgowych przynosi wiele korzyści w każdym obszarze organizacji rachunkowości i działalności przedsiębiorstw. Zaledwie 10\% respondentów wskazało, że korzystanie z usług wyspecjalizowanych firm w zakresie finansów i rachunkowości nie przynosi żadnych korzyści, natomiast nikt nie wskazał na negatywne skutki korzystania $\mathrm{z}$ tych usług.

Zarówno więc przedsiębiorstwa sektora MSP, jak i specjaliści z dziedziny finansów i rachunkowości powinni być zainteresowani coraz szerszą współpracą. Ich aktywne zaangażowanie w działania tego sektora może przyczynić się do zmniejszenia ryzyka działalności tych firm i zmniejszenia wysokiego poziomu likwidacji i upadłości małych i średnich przedsiębiorstw zarówno w skali kraju, jak i w poszczególnych regionach.

\section{Bibliografia}

Chrościcka, A., Płachecki, T., Stasiowski, J. (2010). Raport Identyfikacja kierunków rozwoju sektora MŚP w województwie kujawsko-pomorskim. Toruń: Urząd Marszałkowski Województwa Kujawsko-Pomorskiego.

Ignatiuk, S. (2011). Wpływ przedsiębiorstw z sektora MSP na rozwój gospodarczy północnowschodniego regionu kraju. Economy and Management, 2, 7-20.

Judkowiak, A. (2012). Istota i zakres organizacji rachunkowości. W: K. Winiarska (red.), Organizacja rachunkowości. Warszawa: PWE.

Kiziukiewicz, T. (2002). Organizacja rachunkowości w przedsiębiorstwie. Warszawa: PWE.

KPMG (2015). Polska - Nowoczesne Centrum Usług Biznesowych w Centrum Europy. Warszawa. Pobrano z: https://www.kpmg.com/PL/pl (25.11.2015).

Kuźma, M. (2015). Czym jest i na czym polega outsourcing. Pobrane z: http://www.firma. egospodarka.pl/12027,Czym-jest-i-na-czym-polega-outsourcing,2,47,1.html (31.01.2015).

Łapiński, J., Nieć, M., Rzeźnik, G., Węcławska, D. (2015). Przedsiębiorczość i perspektywy rozwojowe sektora MSP w Polsce. W: A. Tarnawa, P. Zadura-Lichota (red.), Raport $o$ stanie sektora matych $i$ średnich przedsiębiorstw $w$ Polsce $w$ latach 2013-2014 (13-53). Warszawa: PARP. Pobrane z: http://badania.parp.gov.pl/images/badania/ ROSS_2013_2014.pdf (27.11.2015).

Martyniuk-Kwiatkowska, O. (2009). Wykorzystanie danych sprawozdawczości finansowej w ocenie działalności małych przedsiębiorstw. Zeszyty Teoretyczne Rachunkowości, 48 (104), 113-124.

Michael, A. (2015). Czy to już czas na outsourcing? Rachunkowość, 7, 74-76.

Nwobu, O., Faboyede, S.O., Onwuelingo, A.T. (2015). The Role of Accounting Services in Small and Medium Scale Businesses in Nigeria. Journal of Accounting - Business \& Management, 22 (1), 55-63.

Power, M.J., Desouza, K., Bonifazi, C. (2010). Outsourcing. Podręcznik sprawdzonych praktyk. Warszawa: MT Biznes sp. z o.o.

Raluca, S. (2015). Outsourcing accounting - benefits and limits in the current economic environment in Romania. Studies in Business \& Economics, 123-127.

Słownik języka polskiego PWN. Pobrane z: http://sjp.pwn.pl/szukaj/outsourcing.html (1.02.2015).

Trocki, M. (2001). Outsourcing. Warszawa: PWE.

Ustawa z dnia 29 września 1994 r. o rachunkowości, Dz.U. z 2013 r., poz. 330, tekst jedn. z późn. zm. 
Wojciechowski, M. (2015). Outsourcing - co to takiego? Pobrane z: http://www.egospodarka.pl /5805, Outsourcing-co-to-takiego,2,20,2.html (31.01.2015).

Zieliński, J. (2015). Outsourcing doradztwa podatkowego i rachunkowości w matej firmie. Pobrane z: http://abc.online.wolterskluwer.pl (2015.02.12).

\section{Benefits from the Use of Financial and Accounting Services the SMEs Sector of the Kujawsko-Pomorskie}

Keywords: accounting services, financial services, outsourcing, small and medium enterprises

Summary. An increasing number of companies outsource their financial and accounting tasks with a view to obtaining the benefits resulting from achieving a greater efficiency and effectiveness of operations. Contracting out financial and accounting functions to specialist companies brings not only cost savings, but gives access to the knowledge and skills of highly qualified personnel. At present, an increasing development of the outsourcing of financial and accounting functions can be observed. Companies outsource these functions fully or use some of selected areas only. The objective of the article is to present the results obtained by companies of the SMEs sector in the kujawsko-pomorskie province from the use of professional financial and accounting services. The research conducted found that the most common area used in the outsourcing of financial and accounting functions is bookkeeping. Planning and preparation of accounting records and financial reporting are on a par with bookkeeping. As a result of entrusting tasks to specialist companies in the field of finance and accounting, businesses gain a number of benefits in every area of its operations.

Translated by Jolanta Wiśniewska

\section{Cytowanie}

Wiśniewska, J. (2016). Korzyści świadczenia usług finansowo-księgowych w MSP województwa kujawsko-pomorskiego. Marketing i Zarzadzanie, 2 (43), 193-204. 